\title{
A STUDY OF RHEUMATIC DISEASE IN A CANADIAN INDIAN POPULATION*
}

\author{
BY
}

\author{
H. S. ROBINSON, J. P. GOFTON, AND G. E. PRICE $\dagger$ \\ Canadian Arthritis and Rheumatism Society, Vancouver, B.C.
}

Rheumatoid arthritis is an endemic disease known throughout the world. Its aetiology is unknown. No meaningful differences in prevalence rates between populations or races have so far been established, although Lawrence (1959) has shown a small difference in prevalence between rural and urban communities. Large geographical differences in prevalence are unlikely to have escaped detection by ordinary methods of study. The possibility remains that small but distinct differences exist between populations or races of an order which would require close statistical study for valid definition. The finding of a small but significant difference in disease prevalence between such groups would invite further study in the hope that some light might be shed on the cause or occurrence rate of the disease.

Numerous reports of the prevalence of rheumatoid arthritis have appeared in recent years. One of the most complete is that of Lawrence (1961) and his associates in Wensleydale and Leigh in Great Britain (W.-L. study). This survey of a random sample from rural and urban areas including all persons aged 15 and over serves as a useful basis for the design of a comparative study.

\section{Survey of the Haida Indians}

The rheumatic disease survey of the Haida Indians, reported in this paper, was designed to allow the closest comparison to the W.-L. study. With the co-operation of the Haidas a number of supplementary studies were carried out, including an attempt to uncover cases of Marie-Strümpell spondylitis, the prevalence of which is not as well defined as that of rheumatoid arthritis. Our findings among the Haidas suggest that further interest in this disease is warranted.

* Through the assistance of Federal Health Grant No. 609-7-48 and the Canadian Arthritis and Rheumatism Society, B.C. Division.

$\dagger$ Canadian Arthritis and Rheumatism Society, Research Fellow.
A uric acid estimation was carried out on samples of serum from all respondents in this study. Surveys of racial groups, such as the Filiponos (Decker and Lane, 1959), have suggested that differences may be present in the mean levels of serum uric acid between population groups.

It was considered desirable to make the closest compatison between serological results in the Haidas and the W.-L. study. Samples of frozen serum were, therefore, submitted to Dr. John Ball of Manchester, England, and through his co-operation the S.C.A.T. test was done by the same techniques and in the same laboratory for both populations. Coincidentally, a latex-fixation test by standard techniques and a sensitized human " $O$ " cell test was carried out by Dr. Denys Ford at the University of British Columbia. Through the co-operation of Dr. Joseph Bunim of the National Institutes of Health, Bethesda, Maryland, a bentonite flocculation test was also done on similar samples of the same frozen serum. These various serological techniques are widely used and may profitably be employed in epidemiological surveys. The co-operation of these three laboratories enabled us to compare the results of the various tests on aliquots of serum collected at one time from one population.

An extensive blood geno-type study was also undertaken and will be reported separately.

The present paper includes a description of the characteristics of the population studied and the methods and criteria employed.

The findings on Marie-Strümpell spondylitis which are already available are considered of sufficient interest to be published in advance of the other findings. The several results of the various other aspects of this survey will be reported in later issues of this Journal as they reach completion.

The serological comparisons await final completion of the tests in the various laboratories. 
The findings on the prevalence (actually the pointprevalence as defined by Cobb, Warren, Merchant, and Thompson, 1957) of rheumatoid arthritis and the comparison with the W.-L. study will be available when Dr. J. S. Lawrence and his associates have completed their reading of the Haida $x$-ray films.

\section{Population}

The Haidas are a native Indian group who live on the Queen Charlotte Islands off the continental coast of British Columbia, 500 miles to the northwest of Vancouver. Before the appearance of the white man the Haidas numbered some 8,000. In the late 18th century they comprised a vigorous primitive population in a number of well-organized communities. Some genetic intermingling occurred between the Haidas and the white visitors. During the 19th century the Haida race was reduced drastically, mainly through the ravages of disease, and their lowest ebb was reached about two generations ago when they numbered less than 800 individuals. In recent years the population has increased to over 1,100 with a relative preponderance of younger age groups (Jenness, 1960) (Table I). resided in one or other of the two major communities, Masset or Skidegate. A total of 492 individuals were eligible and of these 436 were studied, a completion rate of 88.6 per cent. (Table II).

A brief history was taken and a physical assessment was made of all 436 respondents. Findings of clinical significance were always checked by one or other of the senior authors. Correlation of criteria was made before the study to reduce observer bias to a minimum. The history included an inquiry into the existence of previous or current musculo-skeletal symptoms. The physical assessment focused on the musculo-skeletal system and was extended to other systems including the skin and eyes where appropriate.

A single postero-anterior film of the hands and feet and a lateral film of the cervical spine in moderate flexion were taken on all respondents. When symptoms or objective findings were discovered in the spine, and were not adequately explained by non-rheumatic disease or trauma, an anteroposterior view of the pelvis was also obtained.

Blood was collected from all respondents. Serum was removed by centrifugation and separated into appropriate aliquots and frozen within 6 hours of

TABLE I

POPULATION DISTRIBUTION BY SEX AND DECADE, IN THE HAIDA AND WENSLEYDALE-LEIGH STUDIES

\begin{tabular}{|c|c|c|c|c|c|c|c|c|c|c|c|}
\hline \multirow{2}{*}{ Study } & \multirow{2}{*}{\multicolumn{2}{|c|}{ Sex }} & \multicolumn{7}{|c|}{ Age Group (yrs) } & \multirow{2}{*}{$\begin{array}{c}\text { Total } \\
\text { Persons }\end{array}$} & \multirow{2}{*}{$\underset{\text { (yrs) }}{\text { Mean Age }}$} \\
\hline & & & $15-24$ & $25-34$ & $35-44$ & $45-54$ & $55-64$ & $65-74$ & $75+$ & & \\
\hline \multirow{2}{*}{ Haida } & Males & . & $\begin{array}{c}98 \\
(34 \cdot 6 \%)\end{array}$ & $\begin{array}{c}51 \\
(18 \cdot 0 \%)\end{array}$ & $\begin{array}{c}44 \\
(15 \cdot 5 \%)\end{array}$ & $\begin{array}{c}40 \\
(14 \cdot 1 \%)\end{array}$ & $(10 \cdot 2 \%)$ & $\begin{array}{c}10 \\
(3 \cdot 5 \%)\end{array}$ & $(3.9 \%)$ & 283 & $37 \cdot 35$ \\
\hline & Females & $\cdots$ & $\begin{array}{c}78 \\
(37 \cdot 1 \%)\end{array}$ & $\begin{array}{c}31 \\
(14 \cdot 8 \%)\end{array}$ & $\begin{array}{c}31 \\
(14 \cdot 8 \%)\end{array}$ & $\begin{array}{c}27 \\
(12 \cdot 9 \%)\end{array}$ & $(9.0 \%)$ & $\begin{array}{c}16 \\
(7 \cdot 6 \%)\end{array}$ & $(3.8 \%)$ & 210 & $38 \cdot 00$ \\
\hline \multirow{2}{*}{ W.-L. } & Males & $\cdots$ & $(17 \cdot 2 \%)$ & $\begin{array}{c}194 \\
(15 \cdot 8 \%)\end{array}$ & $\begin{array}{c}220 \\
(17 \cdot 9 \%)\end{array}$ & $\begin{array}{c}270 \\
(22 \cdot 0 \%)\end{array}$ & $\begin{array}{c}165 \\
(13 \cdot 5 \%)\end{array}$ & $\begin{array}{l}112 \\
(9 \cdot 1 \%)\end{array}$ & $\begin{array}{c}53 \\
(4 \cdot 3 \%)\end{array}$ & 1,225 & $44 \cdot 34$ \\
\hline & Females & . & $\begin{array}{c}201 \\
(14 \cdot 9 \%)\end{array}$ & $\begin{array}{c}192 \\
(14 \cdot 3 \%)\end{array}$ & $\begin{array}{c}247 \\
(18 \cdot 3 \%)\end{array}$ & $\begin{array}{c}254 \\
(18 \cdot 9 \%)\end{array}$ & $\begin{array}{c}214 \\
(15.9 \%)\end{array}$ & $\begin{array}{c}167 \\
(12 \cdot 4 \%)\end{array}$ & $\begin{array}{c}72 \\
(5 \cdot 3 \%)\end{array}$ & 1,347 & $46 \cdot 51$ \\
\hline
\end{tabular}

Note: Percentage in each age group shown in brackets

\section{Methods of Study}

The survey was limited to all Indians aged 15 and over on the Reserve Band List who permanently

TABLE II

COMPLETION RATE, BY SEX

\begin{tabular}{cc|c|c|c}
\hline Sex & & No. of Persons & No. Studied & $\begin{array}{c}\text { Completion Rate } \\
\text { (per cent.) }\end{array}$ \\
\hline Male $\ldots$ & $\ldots$ & 283 & 238 & 84 \\
Female $\ldots$ & $\cdots$ & 209 & 198 & 95 \\
\hline Total & $\ldots$ & 492 & 436 & $88 \cdot 6$ \\
\hline
\end{tabular}

the time of collection. It was maintained in a continually frozen state until delivery at the various testing laboratories. The blood geno-type study was done immediately after collection.

$X$-ray films were read in Vancouver by the two senior authors conjointly. An initial comparison with the findings of the W.-L. study revealed differences in the prevalence of erosive disease between the two populations. Through the co-operation of Dr. J. S. Lawrence of Manchester a matched sample of W.-L. films was made available to the Vancouver group. Upon reading these it became apparent that the interpretations made by the 
British observers were more sensitive than those of the Vancouver group. The difference in the prevalence of erosive disease between the two studies might, therefore, be due to inter-observer bias. An adequate comparison between the two populations for the presence of erosive disease will require interpretation of the Haida films by Dr. Lawrence and his group. Inter-observer bias, apparently present, should be largely reduced or eliminated by this cross-exchange of films.

Evaluation of clinical disease in this native Indian population raised some problems. An attempt was made to use the criteria for diagnosis of the American Rheumatism Association, but clinical information on symptoms such as morning stiffness and previous musculo-skeletal pain was found to be unreliable. The respondents were concerned to maintain an affable conversation and a clear-cut history was often unobtainable. This effectively removed important clinical criteria, the availability of which is necessary for the A.R.A. definition of disease by summation of positive criteria. Therefore, all cases of clinical rheumatoid arthritis, defined in this study, displayed unequivocal joint swelling and deformity of a characteristic type and no cases of "probable" disease were defined.

\section{MARIE-STRÜMPELL SPONDYLITIS AMONG THE HAIDA INDIANS}

Among the 436 studied, 25 individuals gave a history of spinal symptoms or iritis or displayed objective evidence of spinal disease. An anteroposterior view of the pelvis was taken in all of these cases.

$X$-ray changes in the sacro-iliac joints were graded according to the classification of Carter (1962).

Grade I (Mild): Blurring of joint spaces, slight irregularity of margins, decalcification and/or marginal sclerosis only.

Grade II (Moderate): Early erosions (irregular margins), with or without Grade I features.

Grade III (Severe): Fusion of joints, or sclerosis and marked erosions.

Results.-By our screening procedures ten male cases of unequivocal Marie-Strümpell spondylitis were found. Nine of the ten had characteristic radiological changes and advanced clinical disease with restricted movement of the spine and limited chest expansion. The tenth, a 19-year-old youth, had symptoms of low back pain and well-defined changes in the sacro-iliac joints but no limitation of spinal movement.

These ten cases represent a prevalence of $4 \cdot 2$ per cent. of the 238 adult male respondents. This is the mean prevalence as the term is used by Lawrence (1961), or a minimum prevalence of 3.6 per cent. of the total adult male population of 283 individuals.

Ten cases represents a prevalence of $2 \cdot 3$ per cent. of the combined male and female respondents numbering 436 (Table III).

Eight of the ten individuals had peripheral joint complaints at some time in the past, although only two (Cases 3 and 7) had residual evidence of joint damage or restriction.

Five of the ten had suffered from inflammation of the eyes on one or more occasions. Eye problems of various kinds are relatively common in this population. In three patients the history and current findings were compatible with previous attacks of iritis.

TABLE III

PARTICULARS OF TEN CASES OF MARIE-STRUMPELL SPONDYLITIS, SHOWN IN ORDER OF AGE

\begin{tabular}{|c|c|c|c|c|c|c|c|c|c|c|c|c|}
\hline \multirow{2}{*}{$\begin{array}{l}\text { Case } \\
\text { No. }\end{array}$} & \multirow{2}{*}{$\underset{\text { (yrs) }}{\text { Age }}$} & \multirow{2}{*}{$\begin{array}{c}\text { Total } \\
\text { Male } \\
\text { Popula- } \\
\text { tion }\end{array}$} & \multirow{2}{*}{$\begin{array}{c}\text { No. of } \\
\text { Males } \\
\text { Examined }\end{array}$} & \multirow{2}{*}{$\underset{\text { (yrs) }}{\text { Age }}$} & \multirow{2}{*}{$\begin{array}{l}\text { Positive } \\
\text { History }\end{array}$} & \multirow{2}{*}{$\begin{array}{l}\text { Stiff } \\
\text { Spine }\end{array}$} & \multirow{2}{*}{$\begin{array}{c}\text { Peri- } \\
\text { pheral } \\
\text { Joints }\end{array}$} & \multirow{2}{*}{$\begin{array}{c}X \text { ray of } \\
\text { Sacro-iliac } \\
\text { Joints } \\
\text { (grade) }\end{array}$} & \multicolumn{3}{|c|}{ Serological Tests } & \multirow{2}{*}{$\begin{array}{c}\text { Eye } \\
\text { Lesions } \\
\text { Past or } \\
\text { Present }\end{array}$} \\
\hline & & & & & & & & & Latex & S.C.A.T. & Bentonite & \\
\hline 1 & $15-24$ & 98 & 79 & 19 & + & - & - & 2 & - & - & - & - \\
\hline 2 & $25-34$ & 50 & 42 & 33 & + & + & - & 2 & - & - & - & - \\
\hline \multirow{2}{*}{3} & $35-44$ & 45 & 37 & - & & & & & & & & \\
\hline & $45-54$ & 40 & 34 & 47 & + & + & + & 3 & - & - & - & + \\
\hline $\begin{array}{l}4 \\
5 \\
6\end{array}$ & $55-64$ & 29 & 27 & $\begin{array}{l}59 \\
62 \\
64\end{array}$ & $\begin{array}{l}+ \\
+ \\
+\end{array}$ & $\begin{array}{l}+ \\
+ \\
+\end{array}$ & $\begin{array}{l}\bar{z} \\
\overline{-}\end{array}$ & $\begin{array}{l}3 \\
3 \\
3\end{array}$ & 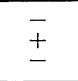 & \pm & $\underline{+}$ & \pm \\
\hline $\begin{array}{l}7 \\
8 \\
9\end{array}$ & $65-74$ & 10 & 9 & $\begin{array}{l}67 \\
70 \\
71\end{array}$ & $\begin{array}{l}+ \\
+ \\
+\end{array}$ & $\begin{array}{l}+ \\
+ \\
+\end{array}$ & $\frac{ \pm}{-}$ & $\begin{array}{l}3 \\
3 \\
3\end{array}$ & $\begin{array}{l}\overline{-} \\
-\end{array}$ & $\begin{array}{l}\overline{-} \\
-\end{array}$ & $\begin{array}{l}- \\
-\end{array}$ & $\begin{array}{l}+ \\
+ \\
+\end{array}$ \\
\hline 10 & $75+$ & 11 & 10 & 75 & + & + & - & 3 & - & - & - & - \\
\hline
\end{tabular}


It is of interest that all of these patients had maintained a good posture despite a minimum of medical attention over the years.

Discussion.-The method used to find cases of Marie-Strümpell spondylitis in this population was relatively insensitive. An adequately sensitive screening test would require a pelvic $x$ ray of all respondents. All ten cases discovered showed classical or advanced disease and it is likely that some mild cases were overlooked. The relatively high prevalence discovered, therefore, probably represents a minimal estimation of the disease rather than an accurate definition of its prevalence.

The literature contains few references to the prevalence rate of Marie-Strümpell spondylitis in population groups. The estimate of West (1949) of 0.05 per cent. incidence in the general population is often quoted.

Two published reports lend themselves to comparison with findings in the Haidas. Julkunen (1962) discovered one case of ankylosing spondylitis among 539 persons over 15 years of age in Heinola, Finland. This represents a prevalence of 0.19 per cent. of the total population studied and may be compared with the prevalence in the Haidas of $2 \cdot 3$ per cent. This difference is highly significant $(P<0 \cdot 01)$.

Ansell (1962) and Ansell, Bywaters, and Lawrence (1962) reported a prevalence of 0.3 per cent. in a random population in Great Britain in the age group 15 and over, compared with the Haida prevalence of $2 \cdot 3$ per cent.

One further reference to the prevalence of MarieStrümpell spondylitis is available. Kellgren and Lawrence (1956), in a study of 380 individuals between the ages of 55 and 64 , found two men with spondylitis. This represents a prevalence of 0.5 per cent. of the combined adult population or 1 per cent. of males only. Corresponding prevalence rates in the 55- to 64-year age group in the Haidas were 6.6 per cent. of the combined population (45 individuals) or 11 per cent. of the males (27 individuals). These differences are also highly significant $(P<0.01)$, since there is no overlap between the 99 per cent. confidence limits for each of the two groups being compared (Mainland, Herrera, and Sutcliffe, 1956).

The age distribution of these ten cases is interesting. Eight of the ten were over the age of 47 and only one was found under the age of 30 . This might mean that early cases in the younger age groups were missed by the case-finding methods employed. If further cases were found among the younger males, more in keeping with the expected age distribution, the true prevalence of the disease would be even higher than was found.
Alternatively, this population may have suffered an increased attack rate of the disease some two or three generations ago. The age distribution of these ten cases might then be interpreted as an indication that the current attack rate in the susceptible younger age group is much reduced. This would be an important and unexpected finding, if proven. Some authorities believe that the occurrence of this disease is related to inflammatory disease of the genito-urinary tract. On this basis one might expect fluctuations in the attack rate.

Some general information was available on the non-respondents. No cases of Marie-Strümpell spondylitis were known among the men, many of whom were unavailable because of their work in heavy logging or fishing. There is no reason to believe that the higher frequency in the older age groups is related to an excessive mortality of younger males with the disease nor does it seem likely that the presence of Marie-Strümpell spondylitis conferred any measure of protection enabling those with the disease to outlive their healthy brethren.

It is possible that this cluster of spondylitics in a native population represents a genetic aggregation perhaps related to a confluence of genetic factors through inbreeding, but available data does not shed any light on this possibility. Family studies of Indian tribes are of dubious value, exchange of names being a common cultural trait. Until recently the Haida society was matriarchal and lines of descent are difficult to trace. Even to-day children are adopted freely and casually. A presumptive family relationship could be established between three spondylitics in one group and between two comprising another group, but the remaining five were apparently unrelated to each other or to members of either group.

\section{Summary}

During the course of an epidemiological survey into the prevalence of rheumatoid disease among the Haida Indians, a search was made for cases of Marie-Strümpell spondylitis. Clinical, radiological, and serological screening studies were employed.

Ten men with unequivocal Marie-Strümpell spondylitis were discovered in a population of 436 adult respondents of whom 238 were males, representing a prevalence of 4.2 per cent. in the adult male population or $2 \cdot 3$ per cent. in the combined male and female population. This finding is in marked contrast to much smaller prevalences reported from other studies. Most cases were found among the older age groups. This may reflect the relative insensitivity of the screening procedures for minimal disease in younger adults or may be significant for reasons yet unexplained. 
This study was made possible through the co-operation and help of a great number of people. Our thanks are extended to Dr. W. S. Barclay and his colleagues in the Department of Indian Affairs and to Dr. G. R. F. Elliot and his colleagues in the British Columbia Department of Public Health and Welfare. We are grateful to the members of the research team. The scope of the project was greatly extended through the co-operation of Dr. J. Ball, Dr. D. K. Ford, Dr. J. J. Bunim, and Dr. J. P. W. Thomas, who made the comparison of laboratory data possible.

Finally, we are greatly indebted to Dr. D. O. Anderson for statistical assistance, to Dr. J. S. Lawrence and Prof. J. H. Kellgren for their valuable advice, and to the Haidas for their whole-hearted co-operation. A substantial contribution to the cost and organization of the project was made by the British Columbia Division of the Canadian Arthritis and Rheumatism Society.

\section{REFERENCES}

Ansell, B. M. (1962). Personal communication.

—, Bywaters, E. G. L., and Lawrence, J. S. (1962). Ann. rheum. Dis., 21, 243.

Carter, M. E. (1962). Ibid., 21, 105.

Cobb, S., Warren, J. E., Merchant, W. R., and Thompson, D. J. (1957). J. chron. Dis., 5, 636.

Decker, J. L., and Lane, J. J., Jr. (1959). New Engl. J. Med., 261, 805.

Jenness, D. (1960). "Indians of Canada", 5th ed. The Queen's Printer, Ottawa.

Julkunen, H. (1962). "Rheumatoid Spondylitis", Acta rheum. scand., Suppl. 4, p. 12.

Kellgren, J. H., and Lawrence, J. S. (1956). Ann. rheum. Dis., 15, 1.

Lawrence, J. S. (1960). In "Proceedings of Isra Symposium, 1959", p. 15. Excerpta Medica Foundation, Amsterdam.

(1961). Ann. rheum. Dis., 20, 11.

Mainland, D., Herrera, L., and Sutcliffe, M. I. (1956). "Statistical Tables for Use with Binomial Samples". Dept. Med. Statistics, New York University College of Medicine.

West, H. F. (1949). Ann. rheum. Dis., 8, 143.

\section{Etude de la maladie rhumatismale dans une} population d'Indiens canadiens

\section{RÉSUMÉ}

Au cours d'une enquête épidémiologique sur la fréquence de la maladie rhumatismale parmi les Indiens Haida, on rechercha des cas de spondylite de MarieStrümpell. La procédure de dépistage comprenait des examens physique, radiologique et sérologique.

Dix hommes atteints de spondylite de Marie-Strümpell indubitable furent trouvés dans une population de 436 personnes adultes, dont 238 furent hommes, ce qui représente une fréquence de $4,2 \%$ de la population adulte mâle ou de $2,3 \%$ de la population adulte totale. Ces résultats contrastent avec de très basses fréquences rapportées dans d'autres travaux. La majorité des cas fut trouvée dans des groupes d'un âge plus avancé. Cela peut indiquer une sensibilité relativement faible des procédés de dépistage de la maladie à un degré minime chez de jeunes adultes ou bien avoir une signification à présent inexplicable.

\section{Un estudio de la enfermedad reumatoide en una población de indios canadienses}

\section{SUMARIO}

En el curso de una encuesta epidemiológica sobre la frecuencia de la enfermedad reumatoide entre los indios Haida, se buscaron casos de espondilartritis de MarieStrümpell. Este estudio comprendió investigaciones clínicas, radiológicas y serológicas.

Diez hombres afectos de indudable espondilartritis de Marie-Strümpell fueron encontrados en una población de $\mathbf{4 3 6}$ adultos, de los cuales 238 fueron hombres lo que representa una frecuencia de $4,2 \%$ en la población de varones adultos o un $2,8 \%$ de la población adulta total. Estos resultados hacen contraste con mucho más bajas frecuencias relatadas en otros trabajos. La mayoría de estos casos perteneció a grupos de edades más avanzadas. Esto puede indicar la relativa insensibilidad de los procedimientos utilizados para detectar la enfermedad en su grado mínimo en los adultos jóvenes o bien tener un significado que se nos escapa. 